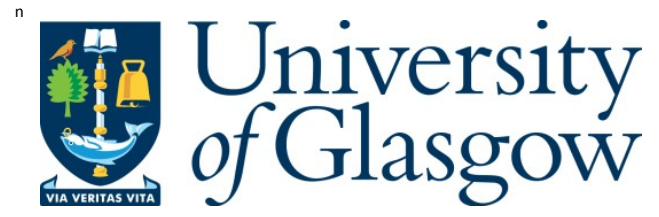

Claassen, C. (2016) Group entitlement, anger and participation in intergroup violence. British J ournal of Political Science, 46(1), pp. 127-148.

There may be differences between this version and the published version. $Y$ ou are advised to consult the publisher's version if you wish to cite from it.

http://eprints.gla.ac.uk/109381/

Deposited on: 09 M arch 2016

Enlighten - R esearch publications by members of the U niversity of Glasgow http://eprints.gla.ac.uk 


\title{
Group Entitlement, Anger and Participation in Intergroup Violence
}

\author{
Christopher Claassen*
}

May 2014

\begin{abstract}
There is little research on the thousands of individuals who take part in intergroup violence. This paper proposes that this participation is motivated by the emotion of intergroup anger, which, in turn, is triggered by a comparison between the intergroup distribution of resources and the distribution that is believed to be desirable. Thus, when another group is perceived to violate group entitlements - by taking jobs thought to belong to the ingroup, for example - anger is experienced and individuals become more willing to take part in violence against the outgroup. Support for this theory is found in a new survey dataset, collected in a slum in South Africa where anti-immigrant violence occurred in 2008.
\end{abstract}

*Department of Government, University of Essex, Wivenhoe Park, Colchester, CO2 7SB, UK, cclaas@essex.ac.uk. Many thanks to James L. Gibson for invaluable advice and support throughout this project. Thanks also to Harry Nakeng, Khathu Mathava, Ntombi Simelane, Keoagile Balatseng, Thabo Rakgwadi and Albert Moleme who helped me carry out the fieldwork in Johannesburg. Three anonymous reviewers and seminar attendees at the University of the Witwatersrand and the 2011 meeting of the American Political Science Association offered very helpful comments and questions. The fieldwork was funded in part by a grant from the Center for New Institutional Social Sciences at Washington University in St. Louis. An online appendix with supplementary tables and replication data are available at http://www. chrisclaassen. com. 
IOLENCE between ethnic, religious, sectarian, national, and partisan groups continues to plague many parts of the world. Despite the prevalence of intergroup violence, there is still considerable uncertainty about why it occurs, and why it occurs where and when it does. One reason is that most scholars take a "top-down" approach, focusing on leaders and group motives ${ }^{1}$ all the while ignoring the question of why thousands of people take part in the murder and mayhem. ${ }^{2}$ Moreover, in contrast to other forms of collective violence - such as civil war-intergroup violence comprises attacks of civilians by civilians; it is thus defined by mass participation. As such, the question of why ordinary people take part looms as especially important when it comes to understanding intergroup violence. The first contribution of this study is to tackle this neglected question of participation, adding to the small body of existing research that examines conflict and violence from the "bottom up". ${ }^{3}$

The second contribution is to use emotion, rather than selective incentives or social pressure, to explain individuals' decisions to join in an attack on another group. Political scientists and social psychologists are increasingly proposing and testing emotional explanations for intolerance, racism, support for violence, participation in elections and protest and ethnic war, but none have so far turned their attention to participation in intergroup violence. ${ }^{4}$ In particular, I use the emotion of intergroup anger ${ }^{5}$ to account for individual decisions about whether to join an attack against another group. Indeed, anger is a powerful mechanism for producing aggression because it shapes both the preference

${ }^{1}$ Dancygier 2010; Olzak 1992; Wilkinson 2004.

${ }^{2}$ Horowitz 1985, 185 was perhaps the first to make this point.

${ }^{3}$ Examples include Humphreys and Weinstein 2008; Fuji 2009; Scacco 2010; Tausch et al. 2011.

${ }^{4}$ For research on emotions and intolerance, see Halperin, Canetti-Nisim, and Hirsch-Hoefler 2009; racism: Banks and Valentino 2012; support for violence: Halperin et al. 2011; Huddy et al. 2005; Kalmoe 2013; Tausch et al. 2011; electoral participation: Groenendyk and Banks 2013; Valentino et al. 2011; protest participation: van Zomeren et al. 2004; Tausch et al. 2011; and ethnic war: Petersen 2002.

${ }^{5}$ Mackie, Devos, and Smith 2000 develop the concept of intergroup emotions. 
for confrontation and beliefs about the risks of taking part. ${ }^{6}$

A third contribution of this research is then to embed the somewhat fleeting explanations of emotion into more enduring and stable evaluations of the intergroup context. To do so, I combine the insights of the appraisal theory of emotions and the large body of conflict research that makes use of some form of intergroup comparison. ${ }^{7}$ Specifically, I propose that feelings of intergroup anger are rooted in evaluations about the intergroup distribution of resources in a society and the distributions that ought to exist. I call these evaluations, respectively, group endowments and group entitlements. When group endowments and group entitlements are incongruent, either because the outgroup are enjoying resources to which they are not entitled, or the ingroup getting less than their share, anger is felt toward the outgroup, and large numbers of ingroup members may become willing to take part in intergroup violence. Participation in intergroup violence is thus not just about who gets what, but also, who deserves what.

While existing individual-level studies of emotions and conflict use samples that are exceedingly unlikely to take part in intergroup violence, such as students or citizens of developed countries, the fourth contribution of this study is to use survey data from a site where intergroup violence has actually occurred. The survey dataset is gathered in Alexandra, a township in South Africa, where a national wave of violence against immigrants began in $2008^{8}$ and where tensions remained at the time of the fieldwork in 2011. Having experienced intergroup violence and - in some cases, actually participatedquestions of participation are both salient and meaningful to the subjects I survey.

The data show that perceived violations of group entitlements are strongly linked with feelings of intergroup anger. These, in turn, are associated with more pronounced intentions to take part in another attack on the other group. Anger, moreover, is a

\footnotetext{
${ }^{6}$ Huddy, Feldman, and Cassese 2007; Lerner and Keltner 2001.

${ }^{7}$ Examples of the appraisal model are Smith and Ellsworth 1985; Frijda, Kuipers, and ter Schure 1989; Lazarus 1991; examples of the intergroup comparisons literature on conflict are Gurr 1970; Horowitz 1985; Runciman 1966; Sidanius and Pratto 1999.

${ }^{8}$ Misago et al. 2010.
} 
significant mediator of the effect of violations of group entitlement. These effects are robust when controlling for a number of other possible explanations, including realistic conflict with the outgroup, the social influence exerted by peers and community leaders and previous participation in intergroup violence.

\section{The Context of the Study: Anti-Immigrant Violence in South Africa}

Perhaps the most familiar feature of the South African political landscape is the faultline between white and black. ${ }^{9}$ As the repression of apartheid began lifting in the early 1990s, however, a new frontier of intergroup tensions began to emerge between black South Africans looking forward to a better life under democracy and immigrants, largely from Zimbabwe and Mozambique, searching for a better life away from the economic hardships of their homelands. ${ }^{10}$

This antipathy has been most marked in the areas where most African immigrants live, the slums and shantytowns that ring South African cities. Vigilante attacks against African immigrants occur with disturbing regularity in these "townships," as they are known in South Africa. ${ }^{11}$ One such incident of anti-immigrant violence occurred on the evening of May 11th 2008 in Alexandra, a densely populated slum near the heart of Johannesburg. ${ }^{12}$ An armed mob in the "Beirut" area of Alexandra went door-to-door searching for foreigners. Anyone who could not pass their test - which was to provide the Zulu word for "elbow" — was beaten. Two were killed that first night.

In contrast to previous incidents, the violence only intensified the following nights. By the 14th of May, Alexandra was in uproar, with thousands of residents toyi-toying, ${ }^{13}$

\footnotetext{
${ }^{9}$ See, for example, Gibson 2004.

${ }^{10}$ Southern African Migration Project 2001

${ }^{11}$ Harris 2004

${ }^{12} \mathrm{My}$ brief account of this violence draws heavily on the more detailed discussion in Monson and
} Arian 2012.

\footnotetext{
${ }^{13}$ The toyi-toyi is a protest dance, often accompanied by singing or chanting, and frequently seen at
} 
attacking people believed to be foreign and clashing with police. Over the next few days, anti-immigrant violence, looting, and the destruction of shacks occurred in other shantytowns around Johannesburg. By the following week, the violence had spread to the centre of Johannesburg and parts of Cape Town. Finally, after three weeks, a measure of calm returned, leaving 62 people dead, 670 wounded and 100,000 displaced. ${ }^{14}$

While narrative accounts of the 2008 riots describe competition over the scarce resources of jobs and government housing, the most thorough research, by Misago and colleagues, finds that the leaders of informal community policing institutions often played an important role in organizing the attacks. ${ }^{15}$ These informal leaders appear to have been using violence to consolidate their positions, which, although meagre, allow for various opportunities to extract rents from residents seeking policing or other government services. The question of why residents of townships like Alexandra so readily took part remains, however, both unexamined and mysterious. This paradox of participation is a feature of the more general literature on intergroup violence, as I argue in the next section.

\section{Intergroup Violence and the Paradox of Participation}

Intergroup violence is, first, a form of collective violence because perpetrators number in the dozens, hundreds, or thousands. Second, the targets are chosen largely because of their presumed membership in a group, ${ }^{16}$ with the groups of interest being those that are widely believed to be an important social category in a given context, such as ethnic,

political rallies and gatherings.

${ }^{14}$ Misago et al. 2010.

${ }^{15}$ Misago et al. 2010; Misago 2012. These "community policing fora", as they are known, emerged as sites of resistance during the struggle against apartheid. In the post-apartheid era, with the police lacking any legitimacy in the townships, the South African government sought to refashion these as sites where the police could interface with the community (Steinberg 2008b). This had the unintended consequence of handing over authority to whoever was occupying the leadership positions of these structures.

${ }^{16}$ Horowitz 2001, 1 
religious, racial, national, and partisan groups. Third, both the victims and perpetrators of intergroup violence are civilians. ${ }^{17}$

Research on intergroup violence and related forms of conflict tends to use explanations situated at two different levels of analysis. The first set of scholars focus on elite mobilization, arguing that intergroup conflict is the result of leaders competing for power. ${ }^{18}$ Brass and Wilkinson, for example, show how elected politicians are involved in intergroup violence in India, while Misago's research in South Africa finds that local leaders organized the attacks of $2008 .^{19}$

A second strand in the literature assumes that groups act in pursuit of some collective goal, with violence resulting when these group preferences collide. Some authors focus on competition over material public goods such as jobs or government housing. ${ }^{20}$ These also emerge as important grievances in interview research conducted after the violence in South Africa. ${ }^{21}$ Although this approach is often termed "realistic group conflict theory", a similar set of explanations, albeit focusing on symbolic group goals such as status or worth, is also prominent in this literature. ${ }^{22}$

Both traditions of research are noticeably silent, however, when it comes to the microlevel mechanisms linking leaders or groups and the participation of thousands of civilians. $^{23}$ Even if leaders do stand to benefit from orchestrating communal violence, it

\footnotetext{
${ }^{17}$ This definition of intergroup violence draws on Horowitz 2001, 17-26; it distinguishes intergroup violence from rebellions (Fearon and Laitin 2003) and violent protests (Finkel, Muller, and Opp 1989), where violence is directed against the state and its representatives, and with ethnic war (Petersen 2002) and genocide (Straus 2006), where regular or irregular military units conduct most of the fighting. The definition includes lynchings and racial violence (Olzak 1992), ethnic riots and pogroms (Horowitz 2001) and anti-immigrant violence(Dancygier 2010).

${ }^{18}$ DeFigueiredo and Weingast 1999; Rabushka and Shepsle 1972; Wilkinson 2004.

${ }^{19}$ Brass 1997; Misago 2012; Wilkinson 2004.

${ }^{20}$ Dancygier 2010; Olzak 1992.

${ }^{21}$ Misago et al. 2010; Steinberg 2008a.

${ }^{22}$ Horowitz 1985; Petersen 2002.

${ }^{23}$ The few exceptions include Humphreys and Weinstein 2008; Fuji 2009 and Scacco 2010.
} 
is not clear how they get large numbers of participants to do their bidding. Nor is it transparent why individuals should take part in pursuit of some group goal, from which they may or may not benefit. This criticism holds whether this group goal as construed as primarily material or largely symbolic: one may desire a higher status for one's group, but also desire not to be injured or arrested because of an attack on a higher-status group.

Participation in intergroup violence is, moreover, accompanied by significant costs. Being caught taking part may have legal consequences, particularly for those who loot or openly attack members of the outgroup. The police may simply use violent, repressive tactics themselves, as they did in South Africa in 2008. The other group might fight back, particularly if their lives or livelihoods are threatened. ${ }^{24}$ Finally, there are also the moral costs of face-to-face violence against other people, seldom mentioned in the political science literature, but convincingly demonstrated by Collins. ${ }^{25}$

The question of participation in intergroup violence is thus not only neglected, it is paradoxical. Indeed, as my argument has suggested, participation in intergroup violence is prey to a well-known paradox: the problem of collective action. The classical theory of collective action argues that unless groups are particularly small, or endowed with members who are likely to act regardless of what the rest of the group does, the group will face a collective action problem where all prefer to free ride rather than take part. ${ }^{26}$ Yet even for such "latent" groups Olson argues that collective action is possible. However, selective incentives - either punishments of nonparticipants, or inducements for participants - are necessary.

Researchers who have applied the theory of collective action to situations of conflict and violence have identified four varieties of selective incentives that are provided, two being punishments and the other two being inducements. ${ }^{27}$ Participants might be

\footnotetext{
${ }^{24}$ Dube 2010.

${ }^{25}$ Collins 2008, 41-43.

${ }^{26}$ Olson 1965.

${ }^{27} \mathrm{~A}$ fifth mechanism is commonly used in the psychological literature on collective action: the belief that the group can effect change. This group efficacy, however, is linked with normative rather than
} 
offered payments in cash or kind, contingent on their participation or, on a related note, may be able to reward themselves through looting of the target groups' possessions. ${ }^{28}$ Leaders might also seek to shape the incentives of would-be participants through coercion, punishing those who do not participate. ${ }^{29}$ Perhaps the most prevalent explanation for participation in conflict, however, is social pressure supplied by other members of the community. ${ }^{30}$

There are, however, problems with all of these explanations when it comes to participation in intergroup violence. First, episodes of intergroup violence are chaotic and confusing: they diffuse over space, with perhaps many battlefronts, and ebb and flow over time. ${ }^{31}$ They also draw attention, thus attracting numerous bystanders as well as participants. ${ }^{32}$ Participants themselves may be more or less involved. Some lead the attacks, others may act more as cheerleaders. Bystanders may become participants as the violence develops, or the reverse. ${ }^{33}$ It would therefore appear to be very difficult, if not impossible, for either leaders or other members of the community to monitor who participates and who does not. Without effective monitoring, threats of punishment or promises of reward are not credible.

Second, the leaders or organizers of intergroup violence are unlikely to be able to reward participants. In the South African case - one of the few where leaders have been identified $^{34}$ - they are themselves poor township residents, who do not have the means to non-normative collection action Tausch et al. 2011; van Zomeren et al. 2004. Participation in intergroup violence is clearly the latter so I do not consider this mechanism here.

${ }^{28}$ Payments: Humphreys and Weinstein 2008; Popkin 1979; looting: DiPasquale and Glaeser 1998.

${ }^{29}$ Lichbach 1995.

${ }^{30}$ Fuji 2009; Scacco 2010; Scott 1976; Taylor 1988.

${ }^{31}$ See Horowitz 2001, 56-70.

${ }^{32}$ See video footage of the 2013 anti-Rohingya riots in Burma: http://www . theguardian. com/world/ 2013/apr/22/burmese-police-buddhists-attack-muslims.

\footnotetext{
${ }^{33}$ Horowitz 2001, 73.

${ }^{34}$ Misago et al. 2010.
} 
provide payments to any significant number of participants. ${ }^{35}$ Indeed, Horowitz suggests that some incidents of intergroup violence actually have no leaders, or perhaps only "endogenous leaders", who arise only at moments of conflict, before disappearing back into the masses. ${ }^{36}$ Nor does it appear that leaders can promise access to valuable public goods. In Alexandra, the jobs or housing that residents desire are allocated by the market and the state, respectively, and thus cannot be credibly promised by community policing leaders.

Finally, although looting occurs in intergroup violence, victims may be poor, as they were in the South African case, while participants are numerous. The ex ante expectations of gain from looting would thus appear to be quite low. In many cases, possessions are burnt or destroyed rather than looted, and in some instances, as with the Ayodhya riots in India, in 1992, destruction is the goal. ${ }^{37}$ Looting may well be an epiphenomenon that is parasitic on the occurrence of intergroup violence.

This paper thus departs from the selective incentive mechanisms that are frequently used to explain participation in conflict and turns, instead, to an emotional mechanism. Emotions have a compulsive quality, ${ }^{38}$ and are thus ideal for understanding the aggressive and non-normative behavior of taking part in a mob attack on another group. As I argue in the next section, anger is the emotion that is particular interest because it has a dual effect: it provides both the motivation for aggression and the means by which the risks, dangers, and normative costs of participation are overcome.

\section{The Emotional Pathway to Participation}

Emotions have re-emerged as explanations for several political attitudes and behaviours. Of particular relevance for this study, researchers have previously linked emotions to

\footnotetext{
${ }^{35}$ Note that only one percent of my survey respondents reported that "some" or "many" participants had been paid in 2008 .

${ }^{36}$ Horowitz 2001, 224-226.

${ }^{37}$ On destruction, rather than looting, see Horowitz 2001, 425; on the riot at Ayodhya, see Brass 1997.

${ }^{38}$ Frijda 2008.
} 
intolerance, intergroup prejudice, support for violence and political participation ${ }^{39}$

Perhaps the most prominent account of emotions and conflict is Roger Petersen's Understanding Ethnic Violence. ${ }^{40}$ He develops four models to account for ethnic war in the Balkans, where variables such as the historical relationships between groups and levels of state authority lead to violence via the emotional pathways of "fear", "resentment", "rage" and "hatred". Although Petersen's macrolevel, comparative historical approach does not speak directly to the microlevel question of why some individuals take part and others do not, his theoretical stratagem of using emotion to explain violence, and then linking emotions to more enduring background variables, is one that I adopt here. ${ }^{41}$

There are thus two parts to my model of participation. The first, like Petersen, uses emotion to explain violence, although, in my case, the violence is at the individual level. The second part of the model then seeks to establish the roots of emotional reactions. My theory is about individuals, so these roots are themselves individual attitudes, but are more stable evaluations than emotions.

\section{Explaining Participation}

As Petersen's work suggests, there are a number of different emotions that might cause violence. The most prominent emotional determinant of violent behaviour is, however, anger. ${ }^{42}$ Mackie and Smith develop this long tradition of anger and aggression research

\footnotetext{
${ }^{39}$ Intolerance: Halperin et al. 2011; prejudice: Banks and Valentino 2012 and Brader, Valentino, and Suhay 2008; support for violence: Halperin, Canetti-Nisim, and Hirsch-Hoefler 2009; Huddy et al. 2005; Kalmoe 2013; Tausch et al. 2011; participation: Groenendyk and Banks 2013; Tausch et al. 2011; Valentino et al. 2011.

${ }^{40}$ Petersen 2002.

${ }^{41}$ We might also say that Petersen (and I) use emotion as a mediating variable. While strictly true, this treatment of Petersen's theory suggests that his contextual variables are widely accepted explanations for conflict, and his contribution is to explain how these factors lead to violence. This is not quite the case given the continued debate about what causes conflict. Instead, I prefer to emphasize the two components of these models.

${ }^{42}$ Averill 1982; Berkowitz 1993.
} 
into an intergroup anger theory of participation in collective action. ${ }^{43}$ Anger has a number of cognitive and behavioural features that make aggression more likely: an increased desire for confrontation, reduced perceptions of risk, a diminished role for risk in decisionmaking and a superficial and stereotypical pattern of decision-making. ${ }^{44}$ Intergroup rather than merely interpersonal anger is then possible because when social groups are salient, individuals tend categorize themselves into one of the available groups, identify with their group, take the goals and values of the group as their own and, most importantly, experience emotions on behalf of their group and directed at another group. ${ }^{45}$

Other researchers have proposed other emotional pathways to conflict and violence. Di Figueiredo and Weingast foreshadow Petersen in claiming that fear produces ethnic conflict; ${ }^{46}$ Tausch and colleagues argue that while anger leads to support for normative collective action, contempt produces support for non-normative collective action; and Halperin shows that anger is only linked with support for state violence among individuals who hate the outgroup. ${ }^{47}$

Thus, while anger is the emotion most clearly linked with aggression and participation in risky collective action, there are at least four rival explanations: fear, hatred, contempt and resentment. Fear is the least promising of these, being both theoretically and empirically associated with withdrawal and risk aversion. ${ }^{48}$ Multiple lines of evidence in research on basic emotions shows that hatred and resentment are in fact variations within the same "emotion family" of anger. ${ }^{49}$ Hutcherson and Gross find that contempt is

${ }^{43}$ Mackie, Devos, and Smith 2000.

${ }^{44}$ Averill 1982; Bodenhausen, Sheppard, and Kramer 1994; Huddy et al. 2005; Kulik and Brown 1979; Lerner and Keltner 2001.

${ }^{45}$ Mackie, Devos, and Smith 2000. See also van Zomeren et al. 2004.

${ }^{46}$ DeFigueiredo and Weingast 1999.

${ }^{47}$ Halperin et al. 2011.

${ }^{48}$ Huddy et al. 2005; Lerner and Keltner 2001.

${ }^{49}$ Using data on recognition of facial expressions to categorize emotions, Ekman 1992 comes up with a list of seven: happiness, fear, surprise, anger, distress, disgust and contempt (Ekman 1972, 1992). Applying cluster analysis to data on 135 emotion words, Shaver and colleagues find six main clusters: 
most closely associated with an appraisal that the other party is incompetent,${ }^{50}$ suggesting that if contempt plays a role in intergroup conflict, its influence is limited to contexts where a powerful group encounters an oppressed and downtrodden minority group. This is not the case in the local-immigrant conflict in South Africa, nor is it the case in many examples of intergroup violence where higher status groups are attacked. ${ }^{51}$

The most plausible emotional determinant of participation in intergroup violence remains anger, particularly intergroup anger. The first hypothesis is thus:

Hypothesis 1. Intergroup anger increases an individual's intention to participate in intergroup violence.

\section{The Roots of Anger}

Existing research shows that anger is caused by appraisals that one has been harmed, and that another party is responsible. ${ }^{52}$ Anger is particularly likely when that harm is perceived as unjust or illegitimate. ${ }^{53}$

love, joy, surprise, happiness, anger and fear (Shaver et al. 1987). Finally, examining the structure and functioning of the brain, Panksepp concludes there are seven innate emotional systems, underpinning the emotions of "fear, anger, sorrow, anticipatory eagerness, play, sexual lust and maternal nurturance" (Panksepp 1998, 47). Despite the very different sources of evidence, there is considerable overlap among these taxonomies. The emotions of resentment/jealousy and hatred, however, do not feature as basic emotions at all.

${ }^{50}$ Hutcherson and Gross 2011.

${ }^{51}$ See the discussion in Horowitz 2001, 178-187. Examples include the attacks of Chinese by Malays in Southeast Asia in the 1950s and 60s, of Indian South Africans by black South Africans in 1949, and of Tamils by Sinhalese in Sri Lanka in the 1950s, 70s and 80s.

${ }^{52}$ Averill 1982; Smith and Ellsworth 1985; Lazarus 1991. This understanding of anger rests on the appraisal model of emotion; see Smith and Ellsworth 1985. The appraisal model treats emotions as discrete entities, and argues that appraisals - evaluations of situations and events - determine which emotion, if any, is triggered. An alternative approach, used by Marcus, Neuman, and MacKuen 2000, among others, boils emotional variation down to one or two dimensions. These dimensional approaches do not conceptualize anger as a distinct emotion and are thus less useful for explaining violent behavior.

${ }^{53}$ Frijda, Kuipers, and ter Schure 1989; van Zomeren et al. 2004. 
The appraisals of harm, blame and injustice find a resonance in theories of conflict and violence that emphasize the power of intergroup comparisons. The first set of such studies examines the role played by intergroup distributions of resources, or inequality, in conflict. ${ }^{54}$ A related strand in the literature makes use of the theory of relative deprivation, which argues that individuals or groups focus on the gap between their own positions and their expectations. ${ }^{55}$ A third set of scholars have focused instead on the rightfulness of each group's position and status: Sidanius and Pratto's "social dominance orientation", Blumer's "group position" theory, and Horowitz's notion of "group entitlement" being the main examples. ${ }^{56}$

I propose, firstly, to combine these theories using the concept of "violations of group entitlement", and secondly, to use this concept as an explanation for why individuals feel anger at other groups in situations where groups are in conflict. Group entitlements are violated either when the outgroup are getting more than they deserve, or the ingroup, less. This concept is composed of four basic group evaluations: ingroup and outgroup endowments ("who gets what") and ingroup and outgroup entitlements ("who deserves what"). When the actual intergroup distribution of material and symbolic resources is incongruent with that which is thought to be normatively desirable, group entitlements are felt to have been violated, the outgroup is blamed, intergroup anger is experienced, and individuals becomes more willing to take part in an attack on the other group. If perceived violations of group entitlement and intergroup anger are widespread, the conditions are fertile for political entrepreneurs to organize a collective event - a march, a meeting, etc. - that may boil over into violence.

Hypothesis 2. Perceived violations of group entitlements result in increased levels of intergroup anger

\footnotetext{
${ }^{54}$ See Lichbach 1989 for a review.

${ }^{55}$ Gurr 1970; Runciman 1966.

${ }^{56}$ Blumer 1958; Horowitz 1985; Sidanius and Pratto 1999.
} 


\section{Data and Methods}

There is something of a tradeoff between internal and external validity in the study of intergroup conflict at the individual level. While the determinants of antipathy and aggression towards outgroups can be tested in experimental studies, research ethics limits the extent to which real groups and samples from violence-prone settings can be used. Given that experimental tests, using student samples and contrived situations, of the link between intergroup anger and confrontational intentions exist, ${ }^{57}$ I sought to gather data from the field; specifically, from a site where asking people about their actual and intended participation in intergroup violence is both realistic and meaningful. I thus follow the lead established by Scacco and Humphreys and Weinstein ${ }^{58}$ in researching participation using a survey of a violence-prone community.

The research site is Alexandra, the Johannesburg township where the anti-immigrant violence began in 2008. There are two advantages to this sample. First, despite the occurrence of anti-immigrant violence in 2008, the tense relationship between locals and foreigners remained at the time of research. Second, the goal of the fieldwork is to survey individuals who might conceivably participate in future intergroup violence. A sample of a larger population would likely catch few such individuals.

The survey was conducted in April and May 2011, using face-to-face interviews of a representative sample of 497 adult South African residents of the area. Satellite photographs and a stratified, two-stage cluster sampling design were used to arrive at a representative sample. The response rate (AAPOR \#3) is $69.2 \%$ (further details are available in the online appendix).

\section{Measurement}

Intentions to Participate in Intergroup Violence. My dependent variable is an individual's willingness or intention to take part in a future attack. In contrast to Humphreys

\footnotetext{
${ }^{57}$ Mackie, Devos, and Smith 2000; van Zomeren et al. 2004.

${ }^{58}$ Humphreys and Weinstein 2008; Scacco 2010
} 
and Weinstein and Scacco, then, I do not use recollections of participation in a previous incident of violence. The reason is that my independent variables, particularly intergroup anger, cannot be validly measured by asking people for recollections of how they felt a few years previously. Furthermore, to avoid gathering a measure of the outcome variable that is antecedent to the explanatory variables, participation needs to be conceptualized as intended future behavior rather than as a recollection of past behaviour.

Similar intentional measures of behaviour have been used in other studies of collective action. ${ }^{59}$ Meta-analyses of the intention-behaviour link show that intentions do have a causal relationship with behaviour. ${ }^{60}$ Nevertheless, there is undoubtedly some slippage between one's intentions to participate in future and actual participation.

In particular, some individuals may profess an intention to participate without any real likelihood of doing so. Others might deny any intention to take part in future but are, in fact, likely to be mobilized because of their social networks. ${ }^{61} \mathrm{I}$ will thus test whether the results are robust across the subgroups who took part and did not take part in the previous attacks, as well as across the subgroups who attend and do not attend community meetings.

I also designed the survey instrument to ensure, as best I could, that respondents were expressing realistic intentions. First I first checked that all respondents were familiar with the 2008 riots before asking questions about participation in this previous episode of violence. Once the memories of 2008 were fresh in the minds of respondents, I moved to questions regarding intentions to take part in future should violence recur.

In particular, respondents were asked if they would (1) join in a group protesting the presence of foreigners in Alexandra if someone asked them to; (2) assault someone or (3) destroy shacks if others were doing so; or, alternatively, if they (4) would help a foreigner hide from the mob. ${ }^{62}$ The responses were recoded as trichotomous indicators

\footnotetext{
${ }^{59}$ Finkel, Muller, and Opp 1989; Tausch et al. 2011.

${ }^{60}$ Webb and Sheeran 2006.

${ }^{61}$ Fuji 2009; McAdam 1986.

${ }^{62} \mathrm{My}$ initial interviews, conducted in Alexandra in June 2010, as well as other interview research
} 
due to small numbers of observations in the middle two categories. Thirty-five percent of respondents said they would definitely take part in an anti-foreigner protest; $12 \%$ said they would definitely assault someone; $15 \%$ expressed a firm intention to destroy shacks; while $60 \%$ claimed that they would definitely not help any victims.

The latent variable of intention to participate in future violence is estimated using a two-parameter logistic item response theory (IRT) model for ordinal data. This model assumes that the latent variable is unidimensional, an assumption that is confirmed by establishing that only the first eigenvalue of the correlation matrix of items exceeds a value of one. The scale is also reliable (Cronbach's alpha $=.87$ ). Parameter estimates of all measurement models are available in the online appendix.

Anger. Anger was measured at three different points in the survey: after short vignettes about foreigners working in Johannesburg and living in government houses in Alexandra, and again after the intergroup endowment and entitlement comparisons (see below). In each of these three situations, respondents were presented with a list of nine emotion words (happy, proud, angry, irritated, jealous, worried, ashamed, disappointed, and no feeling), and asked to choose the words that "best" and "next best" "describe how you feel, as a South African" about the situation just described.

Following previous research, ${ }^{63}$ the words "angry" or "irritated" are both taken as indicators of intergroup anger. There are thus six indicator variables: whether the respondent chose "angry" as either the "best" or "next best" description across the three contexts, and whether they did so again using "irritated". A two-parameter logistic IRT

conducted in Alexandra by Steinberg $2008 a$ and Misago 2012, convinced me that social desirability issues would not present a major problem when asking people about their participation intentions. Despite clearly being an outsider to the area, my initial investigations also yielded several individuals who expressed aggressive intentions regarding immigrants. My survey fieldworkers were also quite experienced at asking sensitive questions. Being black South African residents of Johannesburg, they were also part of the ingroup, and quite likely to be trusted by respondents. More generally, Horowitz 2001, 366-373 notes the absence of remorse characterizing communities that perpetrate deadly ethnic riots.

${ }^{63}$ Mackie, Devos, and Smith 2000; Tausch et al. 2011 
model fit to the set of six measures is used to estimate the latent variable of intergroup anger.

Violations of Group Entitlement. Perceptions of group endowments and group entitlements were obtained using a version of Cantril's scale featuring a ladder with seven "rungs". ${ }^{64}$ The lowest rung was marked "1" and described as a low position in society; the highest rung was marked "7" and presented as a high level of endowment or entitlement. Four questions were asked, corresponding to in- and outgroup endowments and entitlements.

The variable measuring violations of group entitlements is calculated by adding the violation of ingroup entitlements $\left(\right.$ Entitlement $_{\text {in }}-$ Endowment $\left._{\text {in }}\right)$ to the perceived violation of the outgroup's entitlement (Endowment out $_{-}-$Entitlement $\left._{\text {out }}\right)$. Violations of group entitlements, in other words, measures the cumulative number of rungs on the ladder that both the in- and out-groups must move to get from the current distribution of resources between groups to the distributive situation that is desired by the ingroup.

Control Variables. The use of observational data means that it is necessary to consider alternative explanations that may confound any observed relationships among the key variables. First, I control for realistic group conflict by collecting measures of exposure to resource competition with African immigrants. Indicators for being unemployed (which leads to competition for jobs), living in poor quality housing (competition for government housing) and working as an informal trader (competition with foreign traders for customers) are collected. ${ }^{65}$ Second, I control for the effects of elite mobilization using a scale measuring the extent to which respondents heard community leaders blaming immigrants for taking locals' jobs or houses, or acting disrespectfully to locals. I also used fixed effects for community policing sector the capture any unobserved heterogeneity due to leaders. Third, to control for social pressure I use two measures. The first is number

\footnotetext{
${ }^{64}$ Cantril 1965.

${ }^{65}$ Misago 2012.
} 
of community policing meetings the respondent had attended in 2011 , by the time of the survey. The second is an index composed out of three questions asking respondents whether, and to what degree, they had heard their peers blaming immigrants for taking locals' jobs or houses, or acting disrespectfully to locals. Fourth, I control for support for violence, a belief that violence is acceptable and appropriate, ${ }^{66}$ which might be linked with both greater aggression and greater anger. Fifth, I control for the strength of respondents' national identities, which, again, might cause both intergroup aggression and anger. Finally, I also include a number of background factors: socio-economic status, age, the length of time the respondent has lived in Alexandra, level of education, gender and party support.

\section{Empirical Strategy}

Given that the theory has two components, I will test the hypotheses using two regression equations, one for participation intentions, and the other for anger: ${ }^{67}$

$$
\begin{gathered}
\text { Anger }=\alpha_{1}+\beta_{1} \mathrm{GEV}+\psi_{1} \mathbf{X}+\epsilon_{1} \\
\text { PartInt }=\alpha_{2}+\beta_{2} \mathrm{GEV}+\gamma \text { Anger }+\psi_{2} \mathbf{X}+\epsilon_{2}
\end{gathered}
$$

The effects of interest are $\beta_{1}$ and $\gamma$. We might also be interested in the mediation effect: the effect of group entitlement violation, on participation intentions, as expressed through the mechanism of anger. This effect can be calculated simply as the product of $\beta_{1}$ and $\gamma$, but I will also use the simulation technique of Imai and colleagues to provide an uncertainty estimate. ${ }^{68}$

\footnotetext{
${ }^{66}$ Kynoch 2005.

${ }^{67}$ The assumption is that these two equations form a recursive model. In other words, as the theory suggests, the effects flow in one direction from the foundational variable of group entitlement violations to the dependent variable of intended participation. Relaxing this assumption, while desirable, would require some additional information, such as credible instrumental variables (Paxton, Hipp, and Marquart-Pyat 2011).

${ }^{68}$ For the proof of the product rule, see Imai, Keele, and Tingley 2010, 313-314.
} 
Given that the data were gathered using a complex survey design, I use survey linear regressions, which take account of the unequal probabilities of selection into the sample, as well as the additional uncertainty generated by weighting and two-stage cluster sampling. ${ }^{69}$ Missing data were handled using multiple imputation. ${ }^{70}$

\section{Results and Discussion}

\section{Bivariate Results}

I begin by considering bivariate relationship between emotion and participation intentions, on the one hand, and group evaluations and anger, on the other. Figure 1 shows the bivariate correlation coefficient, with $95 \%$ confidence intervals, between participation intentions and each of the emotional reactions I measured.

The figure shows that respondents who feel anger towards immigrants show higher propensities to participate in future violence: the correlation is .48. No other emotion has a significant positive correlation. The other negative emotions show more or less no correlation with participation intentions, indicating that it is not the negativity of anger that matters for violence, but its confrontational, risk-averse action profile. ${ }^{71}$ Both happiness and a neutral emotional response then have a negative correlation with participation intentions; in other words, they are associated with pacific intentions.

Next, I consider the bivariate relationships between anger and evaluations of group endowment and entitlement - the second link in the theoretical model. Figure 2 shows the bivariate correlation between intergroup anger and violations of group entitlement. It also shows the correlations between anger and the four constituent measures of group endowments and entitlements, as well as the correlations between anger and all pairwise combinations of these four constituent measures.

All correlations are significantly different to zero. As we might expect, whereas a

\footnotetext{
${ }^{69}$ See Lumley 2010.

${ }^{70}$ Rubin 1987.

${ }^{71}$ Frijda, Kuipers, and ter Schure 1989; Smith and Ellsworth 1985.
} 
Figure 1. Correlations Between Participation Intentions and Intergroup Emotions

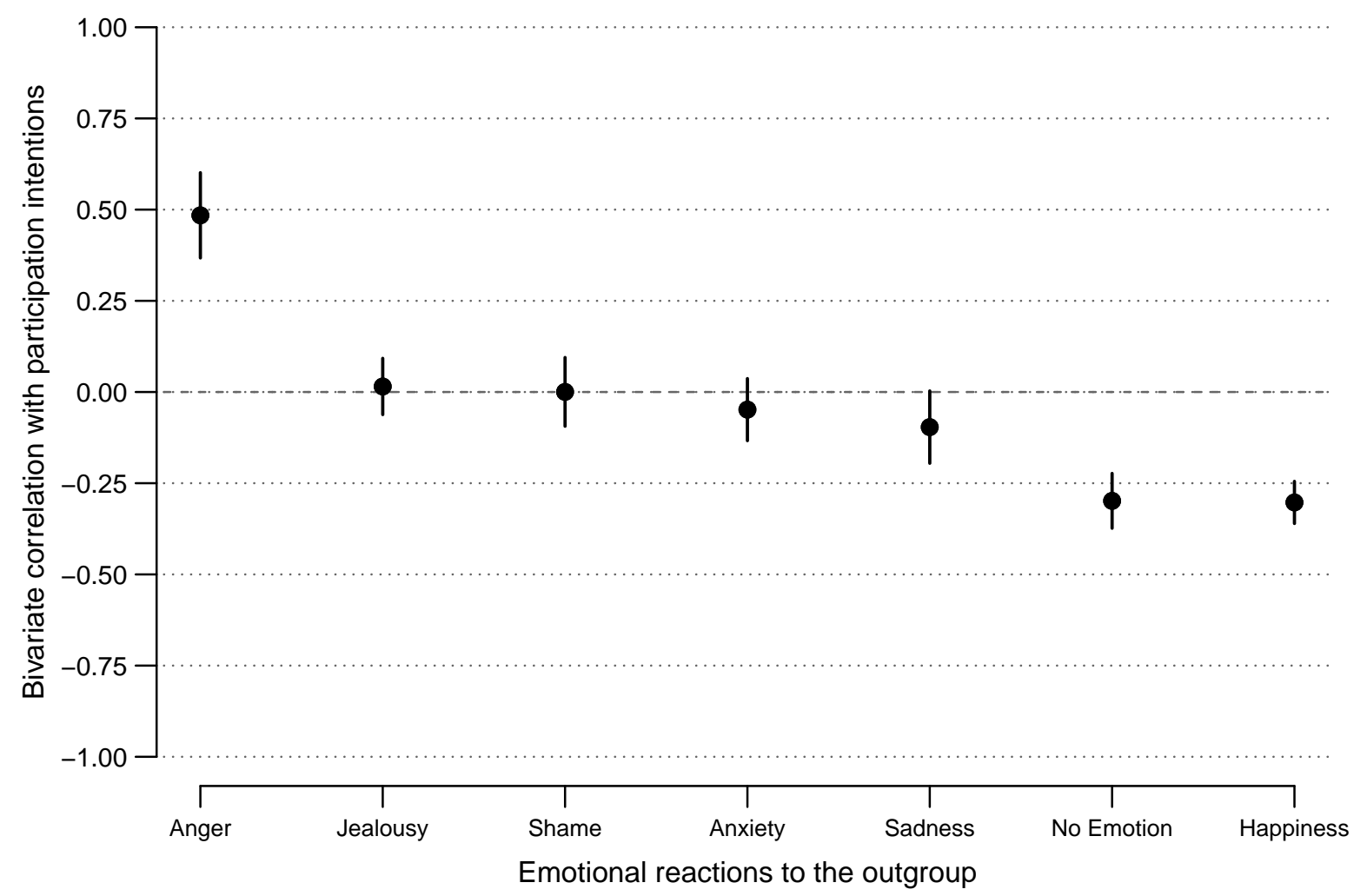

Each point shows the bivariate correlation coefficient between measures of intergroup emotions and participation intentions. While anger is measured using an IRT model; the other emotion measures are counts of mentions of the respective emotion words across the three contexts in the survey. Vertical lines indicate the $95 \%$ confidence intervals.

higher position for the ingroup is associated with lower levels of anger, a higher outgroup endowment is associated with higher levels of anger. On the normative dimension, the position that is deserved by the ingroup has a positive association with anger, with the opposite effect observed for outgroup entitlements. The next four correlations use scales calculated using different pairs of these four group evaluations. All show positive correlations with anger with deserved inequality (ingroup entitlements - outgroup entitlements) and violations of outgroup entitlements (outgroup entitlement - outgroup endowments) having the strongest relationships. Thus, while theories such as relative deprivation focus on the gap between ingroup endowments and entitlements, it appears that the gap between those outgroup endowments and entitlements is at least as important. ${ }^{72}$ And

\footnotetext{
${ }^{72}$ Gurr 1970; Runciman 1966.
} 
Figure 2. Correlations Between Intergroup Anger and Evaluations of Group Endowments and Entitlements

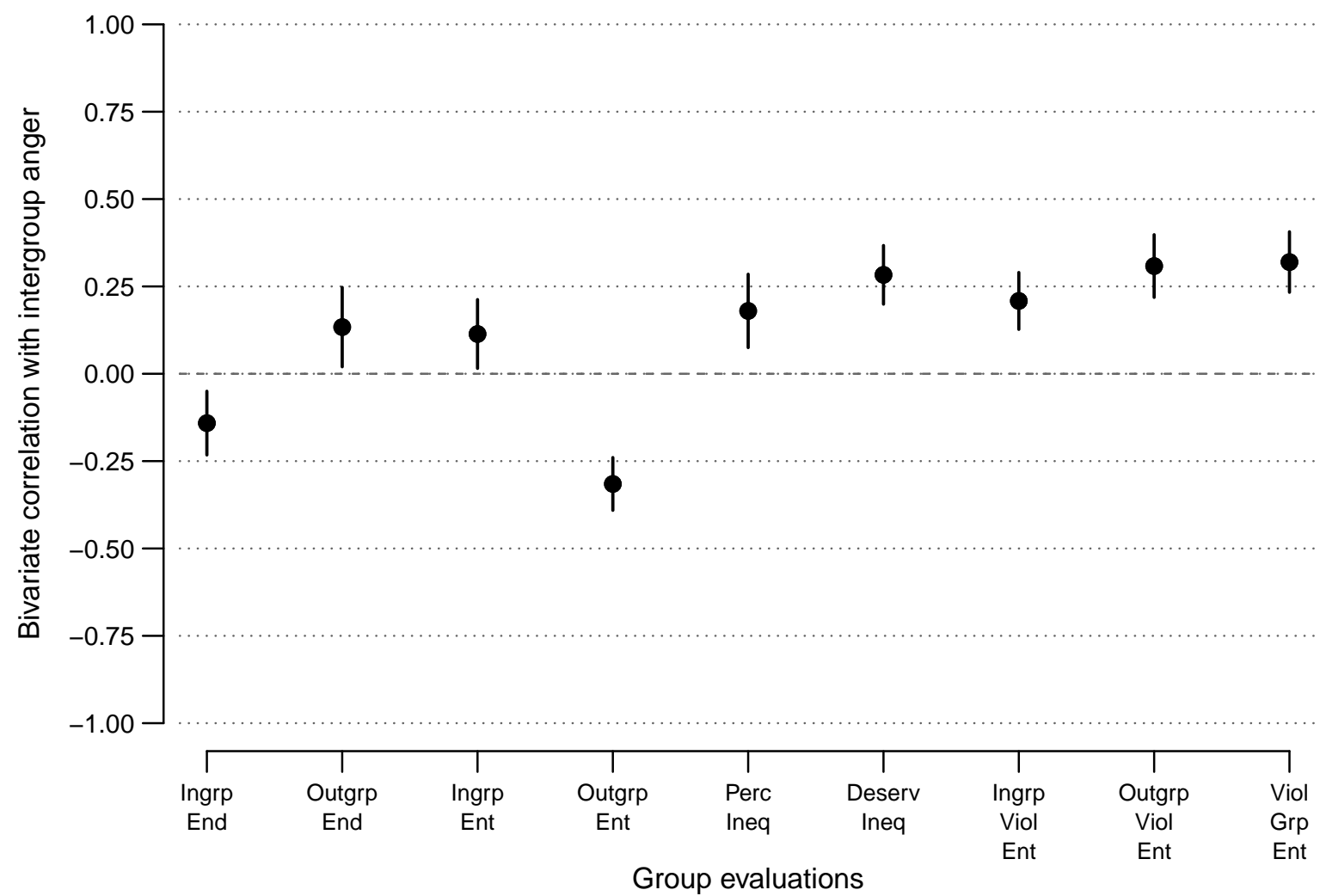

Each point shows the bivariate correlation coefficient between a group evaluation and intergroup anger. The first four group evaluations are the four survey items: ingroup and outgroup endowments and entitlements. The next four are scales calculated using different pairs of these group evaluations: perceived and deserved inequality between groups, and violations of ingroup and outgroup entitlements. The final group evaluation is violations of group entitlements, which uses all four of the group evaluations. Vertical lines indicate the $95 \%$ confidence intervals.

while many researchers use inequality to explain conflict, far fewer consider the level of inequality that the ingroup thinks is deserved. ${ }^{73}$ Finally, the rightmost point in the plot shows the correlation between violations of group entitlement, which uses all four of the basic group evaluations, and intergroup anger. This correlation is the highest of any reported in this figure $(.32) \cdot{ }^{74}$

The bivariate relationships between anger and participation intentions, on the one

\footnotetext{
${ }^{73}$ Sidanius and Pratto 1999 is a notable exception.

${ }^{74}$ This correlation is also significantly higher than the correlations for perceived inequality and violations of ingroup entitlement $(t=4.32$ and 3.58, respectively), using the $t$-test for the difference between two dependent correlations.
} 
hand, and group entitlement violations and anger, on the other, are consistent with the hypothesized model. To control for the effects of the potential confounds I identified earlier, I thus turn to the results of the regression models of participation intentions and intergroup anger. These are displayed in Table 1; participation intentions is used as the outcome variable in Model 1.1, with intergroup anger the outcome variable in Model 1.2.

\section{Model Results}

Table 1 shows that respondents who feel angry at immigrants in Alexandra are indeed significantly more willing to take part in future violence against this outgroup. The effect is substantively large: the standardized regression coefficient for anger is .33.

Table 1. Regressions of Participation Intentions and Intergroup Anger

\begin{tabular}{|c|c|c|c|c|}
\hline \multirow[t]{3}{*}{ Outcome Variable: } & \multirow{2}{*}{\multicolumn{2}{|c|}{$\begin{array}{c}\text { Participation } \\
\text { intentions }\end{array}$}} & \multirow{2}{*}{\multicolumn{2}{|c|}{$\begin{array}{c}\begin{array}{c}\text { Intergroup } \\
\text { anger }\end{array} \\
1.2\end{array}$}} \\
\hline & & & & \\
\hline & $.37^{*}$ & $(.06)$ & & \\
\hline Violations of group entitlement & $.46^{*}$ & $(.10)$ & $.57^{*}$ & $(.09)$ \\
\hline Support for violence & $.29^{*}$ & $(.06)$ & $.21^{*}$ & $(.07)$ \\
\hline Blame from peers & $.09^{*}$ & $(.04)$ & $.14^{*}$ & $(.04)$ \\
\hline Blame from leaders & .05 & $(.07)$ & .07 & $(.07)$ \\
\hline Strength of national identity & .01 & $(.06)$ & $.18^{*}$ & $(.05)$ \\
\hline Employment: not in the labour force & $-.09^{*}$ & $(.04)$ & .05 & $(.05)$ \\
\hline Employment: unemployed & -.03 & $(.03)$ & .02 & $(.03)$ \\
\hline Employment: street trader & -.02 & $(.06)$ & .04 & $(.05)$ \\
\hline Lives in informal dwelling & -.04 & $(.02)$ & -.04 & $(.03)$ \\
\hline No. of community meetings attended & -.01 & $(.06)$ & -.02 & $(.05)$ \\
\hline Socio-economic status & -.12 & $(.08)$ & -.04 & $(.06)$ \\
\hline Party support: none & .02 & $(.03)$ & -.02 & $(.03)$ \\
\hline Party support: opposition & .06 & $(.05)$ & .01 & $(.04)$ \\
\hline Age & -.11 & $(.21)$ & .32 & $(.22)$ \\
\hline Age squared & -.08 & $(.29)$ & $-.67^{*}$ & $(.28)$ \\
\hline Proportion of life spent in Alexandra & $.24^{*}$ & $(.11)$ & .14 & $(.10)$ \\
\hline Gender: Male & $.09^{*}$ & $(.03)$ & .05 & $(.02)$ \\
\hline Level of education & -.07 & $(.06)$ & -.07 & $(.06)$ \\
\hline
\end{tabular}

$N=497 .{ }^{*} p<.05$. Models are survey linear regressions with design-based standard errors in parentheses. All models include an intercept and indicators for community policing sectors. All variables range from 0 to 1.

This effect, moreover, controls for various other factors that could conceivably produce both anger and participation intentions. There are five in particular. Anger 
and willingness to take part in future violence might be thought to be a manifestation of (1) exposure to material competition with the outgroup, (2) the influence of peers, (3) mobilization by leaders, (4) normative support for violence or (5) strength of national identity. The effect of anger is robust to the inclusion of measures of all of these factors. The regressions also control for background factors like poverty, gender and age, which have also been associated with participation in existing research. ${ }^{75}$ The observed relationship between anger and participation intentions thus does not appear to be a spurious correlation produced by the effect of material threat from the outgroup, for example.

However, nor is it likely that the association between anger and participation intentions represents a reversed causal process, where participation intentions causes anger. Such an effect might be though to occur if anger is a response to past violent behaviour, which the theories of self-perception and cognitive dissonance suggest might be possible ${ }^{76}$ Controlling for respondents' behaviour in the previous attacks of 2008 does not, however, alter the observed effect of anger, suggesting that the causal arrow points from anger to participation intentions. ${ }^{77}$

Nor is it very likely that respondents falsely expressed anger during the survey to mask their more venal motives. Three characteristics of the survey suggest that this is unlikely. First, the questions on participation and intentions to participate were asked at the end of the survey, after all the items measuring the independent variables. Second, the anger questions were not posed in the abstract, but were instead asked in reference to fairly detailed vignettes designed to prompt realistic emotional reactions in respondents. Third, emotions were measured by asking respondents to choose a word from a categorical response set. This was expected to reduce the demand characteristics that might result from using a Likert scale response set for each possible emotional reaction (asking, in other words, how angry or irritated respondents felt).

Model 1.2 then presents the results of a regression testing the next component of

\footnotetext{
${ }^{75}$ Horowitz 2001; Scacco 2010; Tishkov 1995.

${ }^{76}$ Bem 1972; Harmon-Jones 2000.

${ }^{77}$ These results are available in the online appendix.
} 
the emotional model: the relationship between group entitlement violations and anger. This effect of group entitlement violations is positive and significant. This effect is also robust to the same set of controls used Model 1.1; indeed, the standardized regression coefficient is .29. much the same size of the bivariate correlation. Thus, in accordance with hypothesis 2 , perceiving a violation of group entitlements appears to lead to higher levels of intergroup anger.

One might question whether the anger has a causal effect on violations of group entitlements rather than the hypothesized effect, which flows from the latter to the former. Although the possibility that each variable influences the other cannot be ruled out without the exogenous variance of an instrumental variable or experimental manipulation, research on the evolutionary roots of anger points toward a "hard-wired" cognitive link between group entitlement violations and the emotional response of anger. ${ }^{78}$ This suggests, at the very least, that there is a causal path from violations of group entitlement to anger.

Finally, we can also interpret these findings in terms of mediation. There is a significant indirect effect of group entitlement violations on participation intentions, exerted through the mechanism of anger. ${ }^{79}$ Anger, in other words, mediates part of the total effect that violations of group entitlements exert on intentions to take part in intergroup

\footnotetext{
${ }^{78} \mathrm{~A}$ variety of authors have argued that anger is an evolved response to a violation of normative order, particularly the fundamental norms that regulated the social life of our ancestors in the form of dominance hierarchies (Axelrod 1986; Fessler 2010; Sell, Tooby, and Cosmides 2009). These dominance hierarchies, moreover, have also been linked with the evolution of deontic or normative reasoning in humans (Cummins 2005). There is a striking resemblance, finally, between the cognitions required to operate within a society governed by dominance hierarchies and the four evaluations that constitute violations of group entitlement: both require an evaluation of the resources enjoyed by oneself and some other party, as well as an understanding of the resources that are entitled by both parties.

${ }^{79}$ There are a number of ways of testing this effect. It can be obtained by taking the product of the two coefficients of interest, $\beta_{1}$ and $\gamma$, which gives a value of .21. A Sobel test can be conducted to verify whether this is significant. It is (test statistic $=4.42$; standard error $=.05 ; p<.001$ ). Finally, one may use the simulation method of Imai and colleagues (Imai, Keele, and Tingley 2010), which gives essentially the same result: mediation effect $=.21 ;$ standard error $=.05$.
} 
violence. Note that anger appears to be a "partial mediator" of group entitlement violations, because this variable also exerts a direct effect on participation intentions, as can be seen in Model 1.2.

\section{Additional Findings}

A further concern that one might have with this analysis is the link between participation intentions and actual participation. The measure of participation intentions might consistently under- or over-estimate the probabilities that certain people would take part in future. Some individuals may profess an intention to participate without any real likelihood of doing so. Others might deny any intention to take part in future but are, in fact, likely to be mobilized because of their social networks. In the former case, respondents underestimate the costs of participation; in the latter, they underestimate the situational determinants. To address both of these concerns, interaction terms between anger and participation in the 2008 attacks, on the one hand, and attendance at the community meetings, on the other, are included. The former model permits a consideration of whether anger explains participation intentions among the subsample who participated in 2008, and thus fully understand the costs and dangers of taking part. The latter model verifies whether anger has a diminished effect among the subsample who are embedded in community social networks, and thus more likely to be mobilized by their peers should violence actually recur. Neither of these interaction effects is significant. ${ }^{80}$

The marginal effects of these interaction terms are then displayed in Figure 3. The figure shows that the point estimates of the effect of anger on intentions to participate in future violence are similar for respondents who took part in the previous attacks (panel 1) - and thus understand the costs of participation - as well as those who did not. The effect of anger, moreover, is similar for respondents who attend meetings (panel 2) - and thus are likely to be faced with the opportunity for participation in future - as well as those who do not attend. The reported effect of anger thus does not appear to be driven by individuals who are unlikely to be mobilized to take part if violence does recur. Nor is it

\footnotetext{
${ }^{80}$ Results available in online appendix
} 
Figure 3. Robustness of the Effect of Anger on Participation Intentions

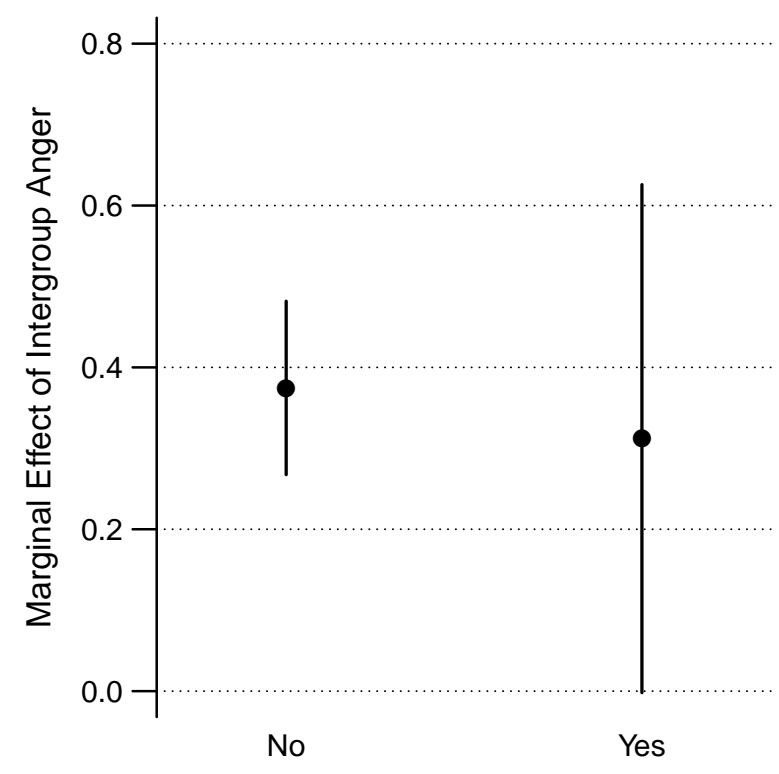

Whether Participated in 2008 Attacks

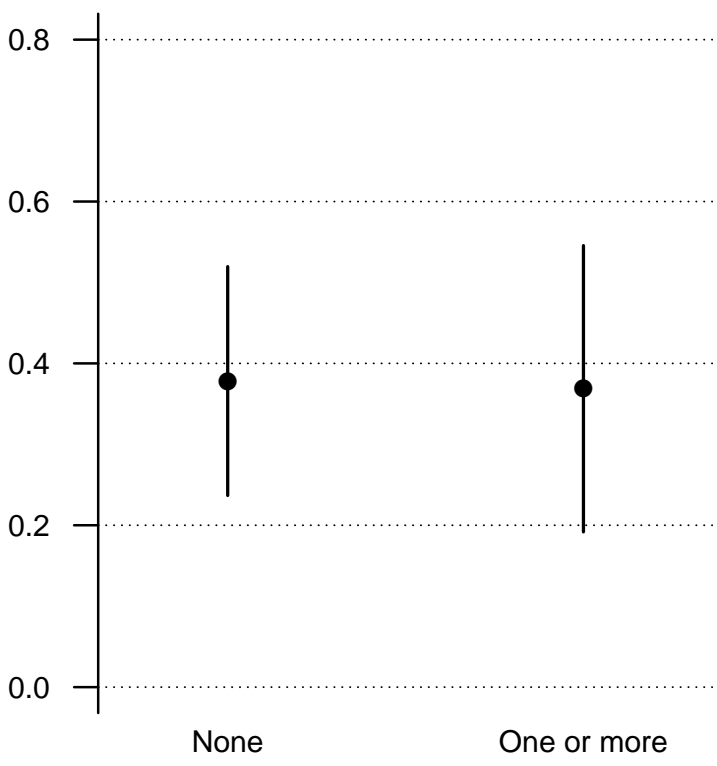

Number of Community Meetings Attended

The points indicate the marginal effects of anger on participation intentions when meeting attendance is 0 and 1 . Vertical bars are $95 \%$ confidence intervals around these estimates. The underlying regression model includes all other covariates used in Model 1.1.

a function of respondents who talk bravely of participation but have little understanding of the costs of taking part in intergroup violence.

A second finding that is worth exploring in detail is the complex relationship between anger, participation, and support for violence. The results have shown that support for violence is a trigger of anger, as we might expect from the social-psychological literature. $^{81}$ It also is associated with a greater willingness to attack the outgroup, as we might expect from the sociological literature on "cultures of violence". ${ }^{82}$ In addition, however, support for violence moderates the effect of anger. ${ }^{83}$ There is a significant interaction term between support for violence and anger, ${ }^{84}$ the marginal effects of which are displayed in Figure 4. The figure shows that the effect of anger on participation

\footnotetext{
${ }^{81}$ In particular, research emphasizing that anger is influenced by the normative costs of aggression.
} See van Zomeren et al. 2004.

${ }^{82}$ Gastil 1971; Kynoch 2005.

${ }^{83}$ I thank one of the anonymous reviewers for suggesting this possibility to me.

${ }^{84}$ Results are available in the online appendix. 
intentions increases to the extent that the respondent supports violence. A combination of support for violence and anger at the outgroup is thus a particularly dangerous brew. Note that, however, despite this moderating effect, anger retains a positive marginal effect on aggressive intentions even for those respondents who strongly oppose violence (the lefthand side of Figure 4).

Figure 4. The Moderating Effect of Normative Support for Violence

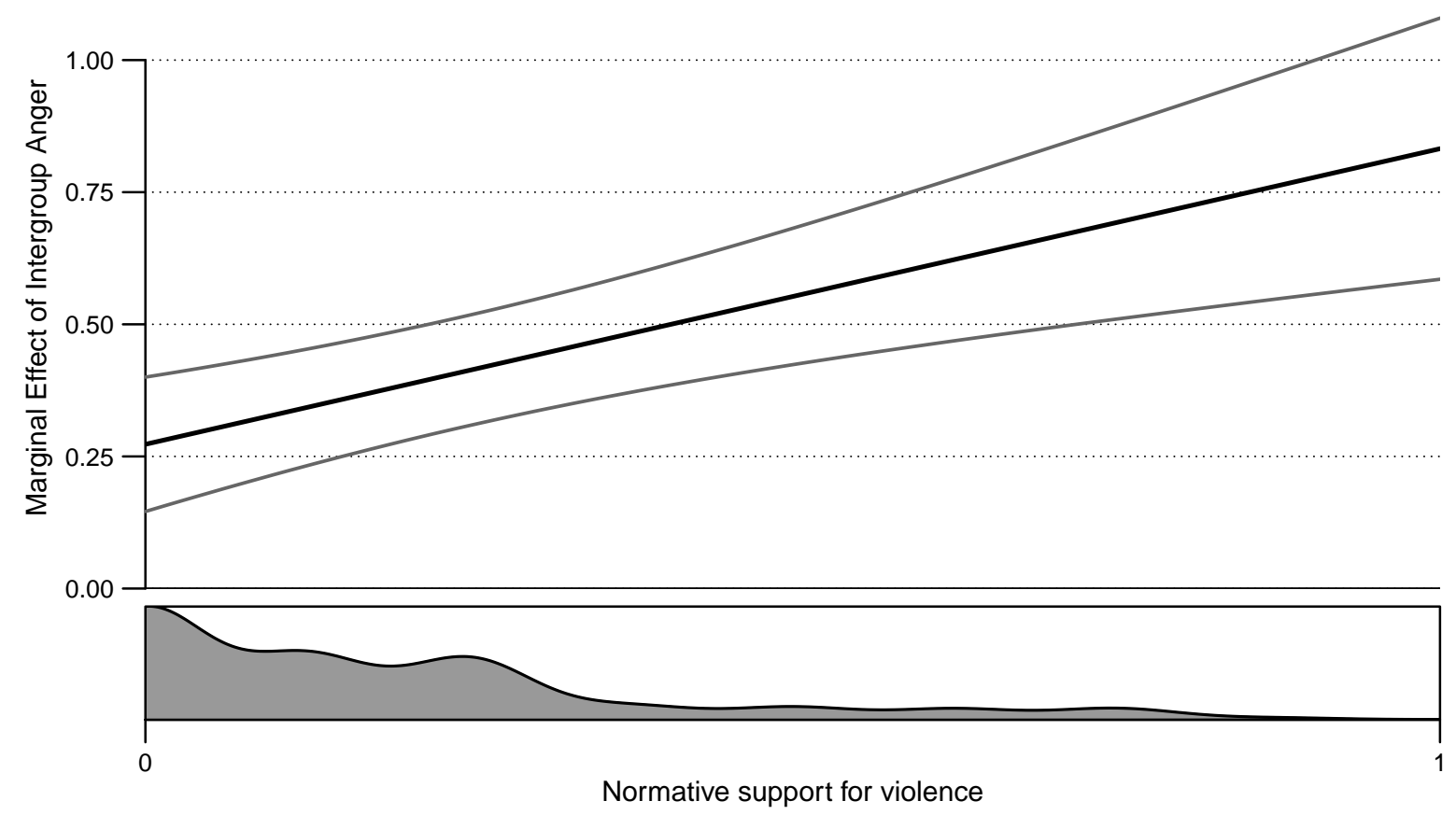

The upper panel of the figure indicates the marginal effects of anger on participation intentions as support for violence varies from its lowest to highest observed values, with $95 \%$ confidence intervals. The lower panel of the figure shows the distribution of the support for violence variable.

Moreover, this dual effect of support for violence (a direct effect on participation and a moderating effect on anger), has an implication for the broader issue of why intergroup violence occurs at all. As Horowitz observes, the incidence of intergroup violence declined precipitously in the West after the Second World War. ${ }^{85}$ The mechanism of anger is itself insufficient to explain this dynamic societal-level variation, because anger is a fairly "hard-wired" reaction to groups that may occur in any setting-educated,

\footnotetext{
${ }^{85}$ Horowitz 2001, 560-5.
} 
industrialized, developed or not. Instead, Horowitz's suggested explanation for the empirical puzzle is "a growing aversion to mass violence" in the West after the War. This conjecture is a historical claim, but its psychological underpinnings find support in my data from Alexandra: anger appears to have an increasingly aggressive effect to the extent that violence is viewed as legitimate. If citizens of Western countries did indeed become largely averse to violence in the latter half of the 20th century, then the mobilizing effects of intergroup anger would have been undercut.

\section{Conclusion}

As hypothesized, feeling angry at another group proves to be an important explanation for why ordinary people are willing to take part in collective violence against that group. This effect of anger is robust to controlling for alternative explanations such as the influence of peers, material competition with the outgroup and mobilization by leaders. I show, furthermore, that intergroup anger is rooted in beliefs that the actual distribution of resources between the in- and outgroups is incongruent with the distribution that is desirable. Participation in intergroup violence is thus about perceptions of who deserves what, as well as who gets what.

This paper uses data collected in a community where intergroup tensions exist and where intergroup violence is only too realistic. While this data-gathering strategy has the advantage of producing measures with construct and external validity, it has the disadvantage of producing observational data and an intentional, rather than behavioural, measure of participation. In future, it would be useful for research to more closely examine the causal links between violations of group entitlement, intergroup anger and participation in intergroup violence. Perhaps the most fruitful research design would be a panel survey of a violence-prone community, with indicators of participation captured after violence occurs, and anger and other independent variables measured in a pre-violence baseline survey.

It bears repeating that this paper focuses on one part of the larger problem of why intergroup violence occurs - the puzzle of why ordinary people join in an attack 
on another group. In addition to a supply of willing participants, the occurrence of an episode of intergroup violence also requires some focal point or collective event where passions can spill over into violence. The model of participation that I have proposed is thus potentially complementary with macrolevel research emphasizing the role that leaders play in organizing intergroup violence. ${ }^{86}$

The model also resonates with macrolevel research on the broader contexts that precipitate intergroup violence. One prominent theory holds that intergroup competition over material resources leads to violence between these groups. ${ }^{87}$ My findings suggest, however, that realistic group competition may not be sufficient for intergroup violence to occur. What also matters is the belief that the other group has no right to take resources that "belong" to the ingroup. Thus, according to my entitlement violation-anger model, at least part of the reason that labour market competition results in intergroup violence may be that it produces a sense that the outgroup have exceeded their entitlements.

\footnotetext{
${ }^{86}$ DeFigueiredo and Weingast 1999; Wilkinson 2004.

${ }^{87}$ Dancygier 2010; Olzak 1992.
} 


\section{References}

Averill, James R. 1982. Anger and Aggression: An Essay on Emotion. New York: Springer.

Axelrod, Robert. 1986. "An Evolutionary Approach to Norms." American Political Science Review 80(4): 1095-1111.

Banks, Antoine J., and Nicholas A. Valentino. 2012. "Emotional Substrates of White Racial Attitudes." American Journal of Political Science 56(2): 286-97.

Bem, Daryl J. 1972. "Self-Perception Theory." In Advances in Experimental Social Psychology, ed. Leonard Berkowitz. Vol. 6 New York, NY: Academic Press pp. 1-62.

Berkowitz, Leonard. 1993. Aggression: Its Causes, Consequences, and Control. New York: McGraw-Hill.

Blumer, Herbert. 1958. "Race Prejudice as a Sense of Group Position." Pacific Sociological Review 1(1): $3-7$.

Bodenhausen, Galen V., Lori A. Sheppard, and Geoffrey P. Kramer. 1994. "Negative Affect and Social Judgment: The Differential Impact of Anger and Sadness." European Journal of Social Psychology 24(1): 45-62.

Brader, Ted, Nicholas A. Valentino, and Elizabeth Suhay. 2008. "What Triggers Public Opposition to Immigration? Anxiety, Group Cues, and Immigration Threat." American Journal of Political Science 52(4): 959-78.

Brass, Paul R. 1997. Theft of an Idol. Princeton, NJ: Princeton University Press.

Cantril, Hadley. 1965. The Pattern of Human Concerns. New Brunswick, NJ: Rutgers University Press.

Collins, Randall. 2008. Violence: A Micro-Sociological Theory. Princeton, NJ: Princeton University Press.

Cummins, Denise D. 2005. "Dominance, Status, and Social Hierarchies." In The Handbook of Evolutionary Psychology, ed. David M. Buss. Hoboken, NJ: Wiley pp. 676-97.

Dancygier, Rafaela M. 2010. Immigration and Conflict in Europe. Cambridge, UK: Cambridge University Press.

DeFigueiredo, Rui, and Barry R. Weingast. 1999. "The Rationality of Fear: Political Opportunism and Ethnic Conflict." In Civil War, Insecurity, and Intervention, ed. Jack L. Snyder, and Barbara F. Walter. New York: Columbia University Press pp. 261-302.

DiPasquale, Denise, and Edward L. Glaeser. 1998. "The Los Angeles Riot and the Economics of Urban Unrest." Journal of Urban Economics 53(1): 52-78.

Dube, Nobayethi. 2010. "Many Shades of the Truth': The Ramaphosa Case Study." Johannesburg, South Africa: Strategy \& Tactics.

Ekman, Paul. 1972. "Universals and Cultural Differences in Facial Expressions of Emotions." In Nebraska Symposium on Motivation, ed. J.R. Cole. Vol. 19. Lincoln, NE: University of Nebraska Press pp. 20783.

Ekman, Paul. 1992. "An Argument for Basic Emotions." Cognition and Emotion 6(3-4): 169-200.

Fearon, James D., and David D. Laitin. 2003. "Ethnicity, Insurgency, and Civil War." American Political Science Review 97(1): 75-90.

Fessler, Daniel M.T. 2010. “Madmen: An Evolutionary Perspective on Anger and Men's Violent Responses to Transgression." In International Handbook of Anger: Constituent and Concomitant Biological, Psychological, and Social Processes, ed. Michael Potegal, Gerhard Stemmler, and Charles Spielberger. New York: Springer pp. 361-383.

Finkel, Steven E., Edward N. Muller, and Karl-Dieter Opp. 1989. "Personal Influence, Collective Rationality, and Mass Political Action." American Political Science Review 83(5): 885-903.

Frijda, Nico H. 2008. "The Psychologists' Point of View." In Handbook of Emotions, ed. Michael Lewis, Jeannette M. Haviland-Jones, and Lisa Feldman Barrett. 3rd ed. New York: Guilford pp. 68-87. 
Frijda, Nico H., Peter Kuipers, and Elisabeth ter Schure. 1989. "Relations Among Emotion, Appraisal, and Emotional Action Readiness." Journal of Personality and Social Psychology 57(2): 212-228.

Fuji, Lee Ann. 2009. Killing Neighbors: Webs of Violence in Rwanda. Ithaca, NY: Cornell University Press, 2004.

Gastil, Raymond D. 1971. "Homicide and a Regional Culture of Violence." American Sociological Review 36(3): 412-27.

Gibson, James L. 2004. Overcoming Apartheid: Can Truth Reconcile a Divided Nation? New York: Russell Sage Foundation.

Groenendyk, Eric W., and Antoine J. Banks. 2013. "Emotional Rescue: How Affect Helps Partisans Overcome Collective Action Problems." Political Psychology forthcoming.

Gurr, Ted Robert. 1970. Why Men Rebel. Princeton, NJ: Princeton University Press.

Halperin, Eran, Alexandra G. Russell, Carol S. Dweck, and James J. Gross. 2011. "Anger, Hatred, and the Quest for Peace: Anger Can Be Constructive in the Absence of Hatred." Journal of Conflict Resolution 55(2): 274-91.

Halperin, Eran, Daphna Canetti-Nisim, and Sivan Hirsch-Hoefler. 2009. "The Central Role of GroupBased Hatred as an Emotional Antecedent of Political Intolerance: Evidence from Israel." Political Psychology 30(1): 93-123.

Harmon-Jones, Eddie. 2000. "Cognitive Dissonance and Experienced Negative Affect: Evidence that Dissonance Increases Experienced Negative Affect Even in the Absence of Aversive Consequences." Personality and Social Psychology Bulletin 26(12): 1490-1501.

Harris, Bronwyn. 2004. "Arranging Prejudice: Exploring Hate Crime in Post-Apartheid South Africa." Race and Citizenship in Transition Series. Cape Town: Centre for the Study of Violence and Reconciliation.

Horowitz, Donald L. 1985. Ethnic Groups in Conflict. Berkeley, CA: University of California Press.

Horowitz, Donald L. 2001. The Deadly Ethnic Riot. Berkeley, CA: University of California Press.

Huddy, Leonie, Stanley Feldman, and Erin Cassese. 2007. "On the Distinct Political Effects of Anxiety and Anger." In The Affect Effect: The Dynamics of Emotion in Political Thinking and Behavior, ed. Ann N. Crigler, Michael MacKuen, and George E. Marcus. Chicago, IL: University of Chicago Press pp. $202-30$.

Huddy, Leonie, Stanley Feldman, Charles Taber, and Gallya Lahav. 2005. "Threat, Anxiety, and Support of Anti-terrorism Policies." American Journal of Political Science 49(3): 610-625.

Humphreys, Macartan, and Jeremy M. Weinstein. 2008. "Who Fights? The Determinants of Participation in Civil War." American Journal of Political Science 52(2): 436-455.

Hutcherson, Cendri A., and James J. Gross. 2011. "The Moral Emotions: A Social-Functionalist Account of Anger, Disgust, and Contempt." Journal of Personality and Social Psychology 100(4): 719-37.

Imai, Kosuke, Luke Keele, and Dustin Tingley. 2010. "A General Approach to Causal Mediation Analysis." Psychological Methods 15(4): 309-34.

Kalmoe, Nathan P. 2013. "From Fistfights to Firefights: Trait Aggression and Support for State Violence." Political Behavior 35(2): 311-30.

Kulik, James A., and Roger Brown. 1979. "Frustration, Attribution of Blame, and Aggression." Journal of Experimental Social Psychology 15(2): 183-194.

Kynoch, Gary. 2005. "Crime, Conflict and Politics in Transition-Era South Africa." African Affairs 104(416): 493-514.

Lazarus, Richard S. 1991. Emotion and Adaption. New York: Oxford University Press.

Lerner, Jennifer S., and Dacher Keltner. 2001. "Fear, Anger, and Risk." Journal of Personality and Social Psychology 81(1): 146-159.

Lichbach, Mark. 1989. "An Evaluation of 'Does Economic Inequality Breed Political Conflict?' Studies." 
World Politics 41(4): 431-70.

Lichbach, Mark. 1995. The Rebel's Dilemma. Ann Arbor, MI: University of Michigan Press.

Lumley, Thomas. 2010. Complex Surveys: A Guide to Analysis Using R. New York: Wiley.

Mackie, Diane M., Thierry Devos, and Eliot R. Smith. 2000. "Intergroup Emotions: Explaining Offensive Action Tendencies in an Intergroup Context." Journal of Personality and Social Psychology 79(4): $602-616$.

Marcus, George E., W. Russell Neuman, and Michael MacKuen. 2000. Affective Intelligence and Political Judgment. Chicago, IL: University of Chicago Press.

McAdam, Doug. 1986. "Recruitment to High-Risk Activism: The Case of Freedom Summer." American Journal of Sociology 92(1): 64-90.

Misago, Jean-Pierre. 2012. "Disorder in a Changing Society: Authority and the Micro-Politics of Violence." In Exorcising the Demons Within: Xenophobia, Violence and Statecraft in Contemporary South Africa, ed. Loren Landau. Johannesburg, South Africa: Wits University Press pp. 89-108.

Misago, Jean-Pierre, Tamlyn Monson, Tara Polzer, and Loren Landau. 2010. "May 2008 Violence Against Foreign Nationals in South Africa: Understanding Causes and Evaluating Responses." Johannesburg: Consortium for Refugees and Migrants in South Africa / University of the Witwatersrand.

Monson, Tamlyn, and Rebecca Arian. 2012. "Media Memory: A Critical Reconstruction of the May 2008 Violence." In Exorcising the Demons Within: Xenophobia, Violence and Statecraft in Contemporary South Africa, ed. Loren Landau. Johannesburg, South Africa: Wits University Press pp. 26-55.

Olson, Mancur. 1965. The Logic of Collective Action. Cambridge, MA: Harvard University Press.

Olzak, Susan. 1992. The Dynamics of Ethnic Competition and Conflict. Stanford, CA: Stanford University Press.

Panksepp, Jaap. 1998. Affective Neuroscience: The Foundations of Human and Animal Emotions. New York: Cambridge University Press.

Paxton, Pamela, John R. Hipp, and Sandra T. Marquart-Pyat. 2011. Nonrecursive Models: Endogeneity, Reciprocal Relationships, and Feedback Loops. Number 168 in "Quantitative Applications in the Social Sciences" Thousand Oaks, CA: Sage.

Petersen, Roger D. 2002. Understanding Ethnic Violence: Fear, Hatred, and Resentment in TwentiethCentury Eastern Europe. New York: Cambridge University Press.

Popkin, Samuel. 1979. The Rational Peasant: The Political Economy of Rural Society in Vietnam. Berkeley, CA: University of California Press.

Rabushka, Alvin, and Kenneth A. Shepsle. 1972. Politics in Plural Societies: A Theory of Democratic Instability. Columbus, OH: Merrill.

Rubin, Donald B. 1987. Multiple Imputation for Nonresponse in Surveys. New York: Wiley.

Runciman, W.G. 1966. Relative Deprivation and Social Justice: A Study of Attitudes to Social Inequality in Twentieth-Century England. Berkeley, CA: University of California Press.

Scacco, Alexandra. 2010. "Who Riots? Explaining Individual Participation in Ethnic Violence." PhD Dissertation. Columbia University.

Scott, James. 1976. The Moral Economy of the Peasant: Rebellion and Subsistence in Southeast Asia. New Haven, CT: Yale University Press.

Sell, Aaron, John Tooby, and Leda Cosmides. 2009. "Formidability and the Logic of Human Anger." Proceedings of the National Academy of Sciences 106(35): 15073-15078.

Shaver, Phillip, Judith Schwartz, Donald Kirson, and Cary O'Connor. 1987. "Emotion Knowledge: Further Exploration of a Prototype Approach." Journal of Personality and Social Psychology 52(6): 1061-1086.

Sidanius, Jim, and Felicia Pratto. 1999. Social Dominance: An Intergroup Theory of Social Hierarchy and Oppression. New York: Cambridge University Press. 
Smith, Craig A., and Phoebe C. Ellsworth. 1985. "Patterns of Cognitive Appraisal in Emotion." Journal of Personality and Social Psychology 48(4): 813-838.

Southern African Migration Project. 2001. "Making Up the Numbers: Measuring 'Illegal Immigration' to South Africa." Migration Policy Brief No. 3. Cape Town: Southern African Migration Project.

Steinberg, Johnny. 2008a. "South Africa's Xenophobic Eruption." ISS Paper 169. Johannesburg: Institute for Security Studies.

Steinberg, Johnny. 2008b. Thin Blue: The Unwritten Rules of Policing South Africa. Johannesburg: Jonathan Ball.

Straus, Scott. 2006. The Order of Genocide: Race, Power, and War in Rwanda. New York: Cambridge University Press.

Tausch, Nicole, Russell Spears, Rim Saab, Julia C. Becker, Oliver Christ, Purnima Singh, and Roomana N. Siddiqui. 2011. "Explaining Radical Group Behavior: Developing Emotion and Efficacy Routes to Normative and Nonnormative Collective Action." Journal of Personality and Social Psychology 101(1): 129-48.

Taylor, Michael. 1988. "Rationality and Revolutionary Collective Action." In Rationality and Revolution, ed. Michael Taylor. New York: Cambridge University Press pp. 63-91.

Tishkov, Valery. 1995. "'Don't Kill Me, I'm a Kyrgyz!': An Anthropological Analysis of Violence in the Osh Ethnic Conflict." Journal of Peace Research 32(2): 133-49.

Valentino, Nicholas A., Ted Brader, Eric W. Groenendyk, Krysha Gregorowicz, and Vincent L. Hutchings. 2011. "Election Night's Alright for Fighting: The Role of Emotions in Political Participation." Journal of Politics 73(1): 156-170.

van Zomeren, Martijn, Russell Spears, Colin Wayne Leach, and Agneta H. Fischer. 2004. "Put Your Money Where Your Mouth Is! Explaining Collective Action Tendencies Through Group-Based Anger and Group Efficacy." Journal of Personality and Social Psychology 87(5): 649-664.

Webb, Thomas L., and Paschal Sheeran. 2006. "Does Changing Behavioral Intentions Engender Behavior Change? A Meta-Analysis of the Experimental Evidence." Psychological Bulletin 132(2): 249-268.

Wilkinson, Steven I. 2004. Votes and Violence: Electoral Competition and Ethnic Riots in India. New York: Cambridge University Press. 